\title{
Comparisons of carbon storages in Cunninghamia lanceolata and Michelia macclurei plantations during a 22-year period in southern China
}

\author{
NIU Dong ${ }^{1}$, WANG Silong ${ }^{2}$, OUYANG Zhiyun ${ }^{1, *}$ \\ 1. State Key Laboratory of Urban and Regional Ecology, Research Center for Eco-Environmental Sciences, \\ Chinese Academy of Sciences, Beijing 100085, China. E-mail: niudong@cashq.ac.cn \\ 2. Huitong Experimental Station of Forest Ecology, Institute of Applied Ecology, Chinese Academy of Sciences, Shenyang 110016, China
}

Received 23 May 2008; revised 30 June 2008; accepted 07 August 2008

\begin{abstract}
Tree species composition was important for carbon storage within the same climate range. To quantify the dynamics of ecosystem carbon allocation as affected by different tree species, we measured the above- and below-ground biomass accumulation in 22 years, as well as the tissue carbon concentrations of trees in Cunninghamia lanceolata plantation and Michelia macclurei plantation. Results indicated that M. macclurei plantation significantly stored more carbon $\left(174.8\right.$ tons $\left./ \mathrm{hm}^{2}\right)$ than C. lanceolata plantation $\left(154.3\right.$ tons $\left./ \mathrm{hm}^{2}\right)$. Most of the carbon was found in the soil pool (57.1\% in M. macclurei plantation, $55.2 \%$ in C. lanceolata plantation). Tree and soil component of $M$. macclurei plantation possessed significantly higher carbon storage than that of $C$. lanceolata plantation $(p<0.05)$. No significant difference was found in the carbon storage of understory and forest floor. These results suggest that the broadleaved species (M. macclurei) possesses greater carbon sequestration potential than the coniferous species (C. lanceolata) in southern China.
\end{abstract}

Key words: Cunninghamia lanceolata plantation; Michelia macclurei plantation; carbon storage; carbon allocation patterns DOI: $10.1016 / \mathrm{S} 1001-0742(08) 62344-\mathrm{X}$

\section{Introduction}

Forest ecosystems are a major sink of terrestrial carbon, which is dependent on environmental, biogeochemical, and land-management factors. Land use change can have a remarkable effect on ecosystem carbon contents. Such changes are important from the viewpoint of soil fertility and long-term sustainability, and their influence on atmospheric $\mathrm{CO}_{2}$ and global warming (Bouwman, 1990). Reforestation can capture significant amounts of atmospheric carbon, and it is expected to contribute to soil quality and conservation (Schroeder, 1992). However, the effects of tree species composition, developmental stage, soil type, and management practices on forest ecosystem carbon storage should not be neglected (Cannell, 1982; Harmon et al., 1990; Dewar and Cannell, 1992; Grigal and Ohmann, 1992; Yang et al., 2005). To understand the effects of tree species composition on forest carbon storage, it is necessary to examine carbon pools and their allocation patterns in different ecosystems to determine the most appropriate reforestation species.

Cunninghamia lanceolata, an important coniferous timber species, has been widely planted for more than 1000 years in southern China due to its fast growth and good timber quality (Wu, 1984). Planting area has covered 12 million $\mathrm{hm}^{2}$, accounting for about $24 \%$ of all forested area

\footnotetext{
* Corrresponding author. E-mail: zouyang@rcees.ac.cn
}

in China, and the successive cropping system has been widely used (Chen and Wang, 2004). In recent decades, however, this practice has led to remarkably decline in soil fertility and timber productivity because of nutrient depletion and deterioration of physical, chemical and biochemical properties (Feng et al., 1988; Chen et al., 1990) which resulted from successive cropping, whole-tree harvest and site preparation. Fortunately, some scientists have found that planting broadleaved tree could improve the quality of forest land (Feng et al., 1988; Chen et al., 1990). In contrast, few studies examine the change of carbon storage due to broadleaved species and coniferous species in southern China.

The main objective of this study is to quantify the dynamics of ecosystem carbon allocation as affected by tree species. For this, we assessed the overall impact of two typical forest types (i.e., plantations of $C$. lanceolata and Michelia macclurei) on ecosystem carbon allocation patterns, by means of quantifying above- and below-ground carbon pools. This study also provided a management baseline for enhancing the carbon sequestration potential of forest ecosystems.

\section{Materials and methods}

\subsection{Study area}

This study was conducted at Huitong Experimental 
Station of Forest Ecology, Chinese Academy of Sciences (latitude $26^{\circ} 40^{\prime}-27^{\circ} 09^{\prime} \mathrm{N}$ and longitude $109^{\circ} 26^{\prime}$ $\left.-110^{\circ} 08^{\prime} \mathrm{E}\right)$, Hunan Province, China. This experimental station lies at the transition zone from the Yunnan-Guizhou plateau to the low mountains and hills on the southern side of Yangtze River at an altitude of 300-1100 m above mean sea level. The climate of this region is humid midsubtropical monsoon with mean annual temperature of $15.8^{\circ} \mathrm{C}$ with a mean minimum of $1.9^{\circ} \mathrm{C}$ in January and a mean maximum of $29^{\circ} \mathrm{C}$ in July. Therefore, four seasons are divided as follows, spring (March-May), summer (June-August), autumn (September-November) and winter (December-February). The mean annual precipitation was $1200 \mathrm{~mm}$ of which about $67 \%$ occurred between $34 \%$ and 93\% during 1998-2004 (Wang et al., 2008).

The native vegetation being evergreen broadleaved forest typical of the subtropics, with the major species component of Castanopsis spp. and Lithocarpus spp., has almost been extirpated by human activities, and $C$. lanceolata has become the major forest community. After clear-cutting of native broadleaved forest at an altitude of 480-560 m above mean sea level in autumn of 1982 and slash burning in winter, a pure $C$. lanceolata stand and a evergreen broadleaved stand of $M$. macclurei in total 10 $\mathrm{hm}^{2}$ were established in early spring of 1983 . Planting density was 950 trees $/ 100 \mathrm{hm}^{2}$ in the both stands. Tree density was $940 \mathrm{stems} / 100 \mathrm{hm}^{2}$ C. lanceolata in pure stand, and 975 stems $/ 100 \mathrm{hm}^{2}$ M. macclurei in evergreen broadleaved stand at the investigation. Three replicate plots were selected in each of the stands giving three permanent plots of $20 \mathrm{~m} \times 20 \mathrm{~m}$ in size. Chen et al. (2000) documented that the background value, including soil profile characteristics, textures and mineral composition, were almost identical in different plots. All the plots were situated in area of similar soil moisture class, topography, aspect, slope position. The common management practices used in the early stage was: weeding and chemical fertilizer in surface soil around $1 \mathrm{~m}^{2}$ area of tree trunk.

According to US taxonomy, the soil is Oxisol developed from slate and shale. The soils in both stands have developed from the same parent material. Forest soil is 50-70 $\mathrm{cm}$ deep and reddish in colour. Prior to the experiment, soils were sampled at random locations in each permanent plot and analyzed in February 1983. The soil texture is medium-clayey loam (sand $32 \%$, silt $22 \%$, caly $46 \%$ ) and soil $\mathrm{pH}$ ranges from 4.8 to 5.0 (Chen et al., 2000). Soil total $\mathrm{N}$ and total $\mathrm{P}$ were 2.4 and $0.66 \mathrm{~g} / \mathrm{kg}$, respectively.

Soils in each plot were sampled by depth (five replicate cores per plot along a diagonal transect) in March 2005. Soil pH was determined in a 1:2.5 soil-water slurry using a combined glass electrode. Soil organic carbon was also established by the oil-bath $\mathrm{K}_{2} \mathrm{Cr}_{2} \mathrm{O}_{7}$ titration method. Total nitrogen was determined by the semi-micro Kjeldahl method. Available nitrogen was ascertained by a microdiffusion technique after alkaline hydrolysis. Available phosphorus was extracted with a 0.5 $\mathrm{mol} / \mathrm{L} \mathrm{NaHCO}_{3}$ solution ( $\mathrm{pH}$ 8.5). Phosphate-P in solution was analyzed colorimetrically by the formation of a blue phosphomolybdate complex following a reduction with ascorbic acid. Available potassium was evaluated using the $\mathrm{CH}_{3} \mathrm{COONH}_{4}$ extraction method (Lao, 1988) (Table 1).

Table 1 Soil and vegetation properties

\begin{tabular}{lll}
\hline Parameter & $\begin{array}{l}\text { Cunninghamia } \\
\text { lanceolata } \\
\text { plantation }\end{array}$ & $\begin{array}{l}\text { Michelia } \\
\text { macclurei } \\
\text { plantation }\end{array}$ \\
\hline Soil property & & \\
Bulk density $\left(\mathrm{g} / \mathrm{cm}^{3}\right)$ & $1.06(0.03) \mathrm{b}$ & $0.94(0.02) \mathrm{a}$ \\
$\mathrm{pH}$ & $3.99(0.11) \mathrm{a}$ & $4.30(0.11) \mathrm{a}$ \\
$\mathrm{Soil}$ organic carbon $(\mathrm{g} / \mathrm{kg})$ & $20.31(1.19) \mathrm{b}$ & $23.81(1.46) \mathrm{a}$ \\
Total nitrogen $(\mathrm{g} / \mathrm{kg})$ & $1.78(0.10) \mathrm{b}$ & $2.08(0.10) \mathrm{a}$ \\
Total phosphorus $(\mathrm{g} / \mathrm{kg})$ & $0.14(0.01) \mathrm{b}$ & $0.18(0.01) \mathrm{a}$ \\
Total potassium $(\mathrm{g} / \mathrm{kg})$ & $12.85(1.46) \mathrm{a}$ & $14.80(0.84) \mathrm{a}$ \\
Vegetation property & 940 & 975 \\
Average tree density $\left(\mathrm{per} \mathrm{hm^{2 }}\right)$ & 16.0 & 22.7 \\
Average DBH $(\mathrm{cm})$ & 17.9 & 26.2 \\
Average tree height $(\mathrm{m})$ & & \\
\hline
\end{tabular}

* The samples were collected in 0-10 cm depth in March 2005 and determined in December 2005.

DBH: diameter at breast height diameter. Standard deviations are provided within parentheses. Values in the same row followed by the same letter are not significantly different at $p<0.05$ level.

\subsection{Biomass estimation}

In March 2005, three $20 \mathrm{~m} \times 20 \mathrm{~m}$ plots were reestablished at each forest site. The diameter at breast height $(\mathrm{DBH})$ and the height of all living trees were measured. A total of eight standard trees belonging to two dominant species (i.e., four individuals of each of the species $C$. lanceolata and M. macclurei) were harvested for aboveand below-ground measurements of biomass and tissue carbon concentrations.

Aboveground biomass was separated into different tissue types (e.g., stem wood, stem bark, branch, and foliage). The 4-6 representative branches were sampled from each tree at regular intervals over the entire length of the crown. Foliage was collected from each of the sampled branches. The trunk was sectioned into meter-long pieces using a chainsaw. Bark was then collected immediately. For each tree, root samples were obtained in soil blocks by excavation with the assumption that the foreign fine roots collected within the block would be balanced with the intrinsic fine roots left in the soil. All samples were weighed in the field, placed into plastic bags, and kept refrigerated and transported to the lab.

Understory biomass was also determined using destructive sampling techniques (i.e., total harvesting, including roots), within five randomly selected $2 \mathrm{~m} \times 2 \mathrm{~m}$ subplots within each $20 \mathrm{~m} \times 20 \mathrm{~m}$ plot.

Forest floor components (i.e., dead plant material on the forest floor) were also sampled within five $1 \mathrm{~m} \times 1 \mathrm{~m}$ subplots randomly chosen in each $20 \mathrm{~m} \times 20 \mathrm{~m}$ plot. A total of fifteen $1 \mathrm{~m} \times 1 \mathrm{~m}$ subplots were sampled in each forest type. All plant materials collected within these $1 \mathrm{~m}$ $\times 1 \mathrm{~m}$ subplots were sorted into three components: coarse wood with a diameter greater than $2 \mathrm{~cm}$ and height at least $40 \mathrm{~cm}$, litter (leaves and twigs), and the fragmentation layer. Forest floor components were bagged separately and transported to the lab. 


\subsection{Soil carbon pool}

Volumetric samples of mineral soil were collected at different depth for determining carbon concentrations, as well as bulk density. On each plot of two forests from five systematically located points, three samples were taken from the following depth ranges: 0-10, 10-20, 20-40, 40$60,60-80$, and $80-100 \mathrm{~cm}$, and pooled by sampling point and layer.

\subsection{Sample treatment and chemical analyses}

Sealed tree tissue samples, as well as samples collected from the forest floor and understory were weighed in the field and recorded as wet-weight. They were then ovendried at $70^{\circ} \mathrm{C}$ and reweighed to calculate tissue-specific wet-to-dry mass conversion factors.

All plant material samples were ground by means of a mortar and pestle with liquid nitrogen, and the oil-bath $\mathrm{K}_{2} \mathrm{Cr}_{2} \mathrm{O}_{7}$ titration method was used to determine organic carbon (Dong, 1997). Soil samples were air dried and sieved with a 2-mm mesh to remove any vegetation or gravel. Soils were also analyzed for soil organic carbon by the oil-bath $\mathrm{K}_{2} \mathrm{Cr}_{2} \mathrm{O}_{7}$ titration method (Liu, 1996).

\subsection{Statistical analyses}

One-way variance analyses were used to test the significant differences in the various soil chemical properties, carbon concentrations, biomasses, and carbon pools among these treatments. Total forest carbon storage was also compared, including the cumulative carbon storage of trees, understory, forest floor, and soil. When a treatment difference was detected, the Tukey's multiple range test was used to examine the differences of treatment means at the significance level of $p<0.05$. All these statistical analyses were conducted using the SPSS version 11.0.

\section{Results}

\subsection{Tree carbon storage}

Stem wood constituted approximately $60 \%$ of the entire tree mass (Table 2). Although the carbon concentration of all the plant tissues was approximately 45\%, significant differences were observed among specific tissues of the two species (Table 2). And the tissue carbon concentration of $C$. lanceolata is significant lower than that of $M$. macclurei.

The largest tree carbon storage was located in the $M$. macclurei plantation $\left(72.4\right.$ tons $\left./ \mathrm{hm}^{2}\right)$ and was significantly different from that of $C$. lanceolata plantation (66.9 tons $/ \mathrm{hm}^{2}$ ) (Table 2). The carbon storage ranking for aboveand below-ground was identical to the total tree carbon storage, except for stem wood (Table 2).

\subsection{Carbon storage of understory and forest floor}

Significant difference in the understory biomass was found among the two forest types (Table 2). However, no significant differences were observed among the means of the understory carbon storage (Table 2).

A significant difference was also found among the means of the forest floor components collected in the two forest types (Table 2). Biomass of the forest floor in the C. lanceolata plantation was significantly lower than those in the $M$. macclurei plantation, but no significant difference was observed for the carbon storage of forest floor between $M$. macclurei plantation and C. lanceolata plantation.

\subsection{Soil carbon storage}

The combined bulk density and carbon concentration of various soil samples across the forest types provide a general picture of carbon storage at different depths. Significant differences were found when comparing the average surface soil $(0-10 \mathrm{~cm})$ bulk densities and organic carbon concentrations of the two forest types (Fig. 1). Similar differences were also found in other layers, including 10-20, 20-40, 40-60, 60-80, and 80-100 cm layers.

Adjusted by soil bulk density and organic carbon concentration, the soil organic carbon storage in the 0-100 $\mathrm{cm}$ range for the two forest types were also significantly different, with the highest value $\left(99.80\right.$ tons $\left./ \mathrm{hm}^{2}\right)$ in the $M$. macclurei plantation and the lowest value $\left(85.27\right.$ tons $\left./ \mathrm{hm}^{2}\right)$ in the C. lanceolata plantation (Fig. 2).

\subsection{Ecosystem carbon storage and their allocation pat- terns}

Figure 3 summarizes the results obtained for ecosystem carbon storage in the two forest types. Forest carbon

Table 2 Biomass, tissue carbon concentration and carbon storage for plant in two forest types

\begin{tabular}{|c|c|c|c|c|c|c|}
\hline & \multicolumn{2}{|c|}{ Biomass (tons/hm²) } & \multicolumn{2}{|c|}{ Tissue carbon concentration (\%) } & \multicolumn{2}{|c|}{ Carbon storage (tons $/ \mathrm{hm}^{2}$ ) } \\
\hline & $\begin{array}{l}\text { Cunninghamia } \\
\text { lanceolata } \\
\text { plantation }\end{array}$ & $\begin{array}{l}\text { Michelia } \\
\text { macclurei } \\
\text { plantation }\end{array}$ & $\begin{array}{l}\text { Cunninghamia } \\
\text { lanceolata } \\
\text { plantation }\end{array}$ & $\begin{array}{l}\text { Michelia } \\
\text { macclurei } \\
\text { plantation }\end{array}$ & $\begin{array}{l}\text { Cunninghamia } \\
\text { lanceolata } \\
\text { plantation }\end{array}$ & $\begin{array}{l}\text { Michelia } \\
\text { macclurei } \\
\text { plantation }\end{array}$ \\
\hline \multicolumn{7}{|l|}{ Tree } \\
\hline Stem wood & $89.9(4.6) \mathrm{a}$ & $101.5(9.6) \mathrm{a}$ & $48.1(0.78) \mathrm{a}$ & $46.0(0.45) \mathrm{b}$ & $43.2(2.33) \mathrm{a}$ & $46.7(5.40) \mathrm{a}$ \\
\hline Stem bark & $9.5(0.9) \mathrm{b}$ & $16.4(0.8) \mathrm{a}$ & $43.8(0.51) \mathrm{a}$ & $38.2(0.7) b$ & $4.2(0.38) b$ & $6.3(0.39) \mathrm{a}$ \\
\hline Branch & $12.5(1.1) \mathrm{a}$ & $9.7(1.0) \mathrm{b}$ & $44.2(0.84) \mathrm{a}$ & $39.4(0.37) \mathrm{b}$ & $5.5(0.41) \mathrm{a}$ & $3.8(0.51) \mathrm{a}$ \\
\hline Foliage & $12.3(1.1) \mathrm{a}$ & $12.0(2.0) \mathrm{a}$ & $46.5(0.84) \mathrm{a}$ & $43.7(0.39) \mathrm{b}$ & $5.7(0.47) \mathrm{a}$ & $5.2(0.97) \mathrm{a}$ \\
\hline Root & $18.5(1.4) b$ & $25.1(1.9) \mathrm{a}$ & $45.2(0.68) \mathrm{a}$ & $41.4(0.4) b$ & $8.3(0.51) b$ & $10.4(0.88) \mathrm{a}$ \\
\hline Subtotal & $142.7(5.3) b$ & $164.7(8.7) \mathrm{a}$ & - & - & $66.9(2.48) \mathrm{b}$ & $72.4(5.00) \mathrm{a}$ \\
\hline Understory & $3.2(0.3) b$ & $4.0(0.4) \mathrm{a}$ & $38.7(0.62) \mathrm{a}$ & $37.3(0.36) b$ & $1.2(0.14) \mathrm{a}$ & $1.5(0.14) \mathrm{a}$ \\
\hline Forest floor & $1.9(0.2) \mathrm{b}$ & $2.7(0.3) \mathrm{a}$ & $45.8(0.53) \mathrm{a}$ & $39.4(0.41) b$ & $0.9(0.08) \mathrm{a}$ & $1.1(0.10) \mathrm{a}$ \\
\hline Total & $147.8(5.1) b$ & $171.5(8.8) \mathrm{a}$ & - & - & $69.1(2.44) b$ & $75.0(5.08) \mathrm{a}$ \\
\hline
\end{tabular}

Values in the same row followed by the same letter are not significantly different at $p<0.05$ level. 


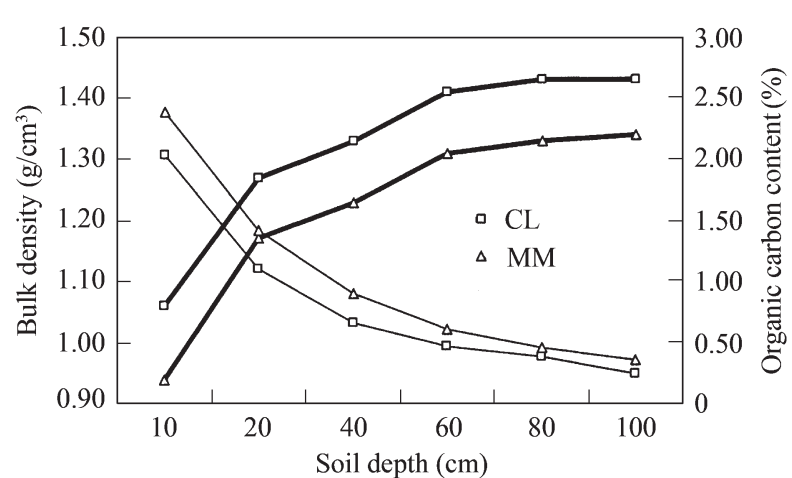

Fig. 1 General pattern of bulk density and organic carbon concentration as affected by depth. CL: Cunninghamia lanceolata; MM: Michelia macclurei. The coarse lines and the thin lines denote bulk density and organic carbon concentration, respectively.

storage in M. macclurei plantation was 174.8 tons $/ \mathrm{hm}^{2}$, which was significantly greater than the storage in $C$. lanceolata plantation measured at 154.3 tons $/ \mathrm{hm}^{2}$. The majority of the carbon was located in the soil pool $(M$. macclurei plantation: 57.1\%; C. lanceolata plantation: $55.2 \%$ ) in the C. lanceolata and M. macclurei plantations. The forest floor and understory contained $1.23 \%-1.49 \%$ of ecosystem carbon pools, respectively, which is less than the other components (Fig. 3).

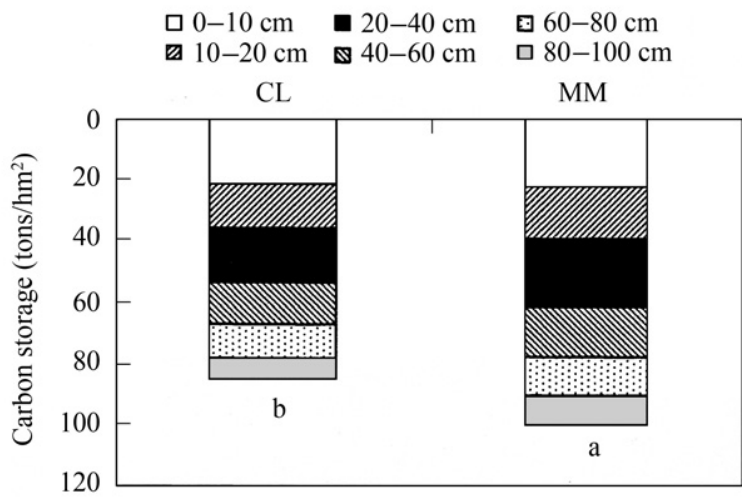

Fig. 2 Soil carbon storage values in the soil $(0-100 \mathrm{~cm})$ in each forest type. CL: Cunninghamia lanceolata; MM: Michelia macclurei. Values followed by the same letter are not significantly different $(0-100 \mathrm{~cm}$ soil carbon storage) at $p<0.05$ level.

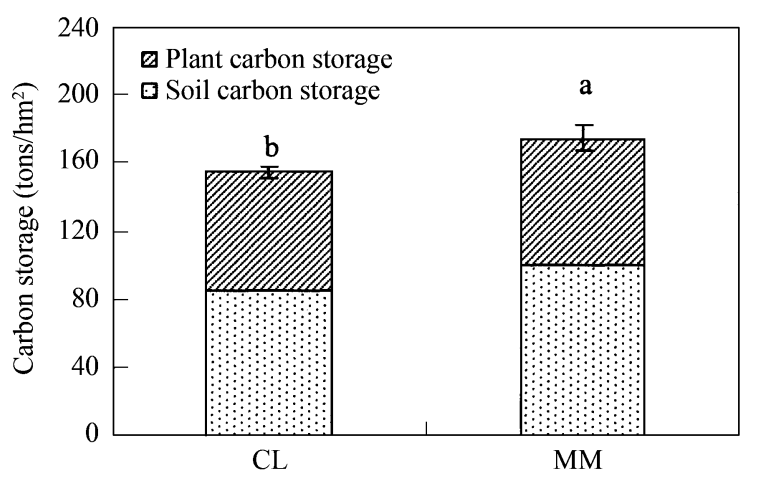

Fig. 3 Carbon storage in plant and soil of each forest type. CL: Cunninghamia lanceolata; MM: Michelia macclurei. Vertical lines denote standard deviations. Values followed by the same letter are not significantly different (forest carbon storage) at $p<0.05$ level.
Michelia macclurei plantation possessed the highest biomass in the components (i.e., trees, understory, and forest floor) and the highest carbon storage in trees and upper $100 \mathrm{~cm}$ of soil (Table 2 and Fig. 2).

\section{Discussion}

In this study, forest carbon storage includes the carbon stored in the trees, understory, forest floor, and top soils (i.e., between 0 and $100 \mathrm{~cm}$ ). Because of the different species selection, the carbon storage and its allocation pattern of forest carbon storage varied significantly.

Compared with $C$. lanceolata plantation, the tree carbon storage in $M$. macclurei plantation was significantly higher (Table 2). The difference is believed to result from species selection during reforestation. M. macclurei is a broadleaved species and the carbon dioxide fixing capacity of a deciduous forest is generally higher than that of a coniferous forest (Zhou et al., 2000).

There exists no significant difference for the carbon storage of understory between the M. macclurei and $C$. lanceolata plantations. However, the biomass of understory and forest floor in $M$. macclurei plantation is significant high than that in $C$. lanceolata plantation.

Soil was the main carbon pool for the two forest types. The difference in soil carbon storage in the different forest ecosystems are believed to result from the root biomass and litter production. Root biomass and litter production constitute important factors affecting the soil organic carbon. The large root biomass and litter production in $M$. macclurei plantation enhanced its soil organic carbon contents. Broadleaved tree species increase litter production and nutrient returns, and are helpful to restore soil fertility of degraded monoculture forests (Wang et al., 2008). The changes in the carbon stocks of the soils in the different forest types might also reflect the differences in quantity and quality of above- and below-ground litter inputs, litter carbon decay (Mo et al., 2002), and root biomass carbon. Yang et al. (2004c) noted that the leaf-litter of Chinese fir possesses higher lignin concentration and lignin/ $\mathrm{N}$ ratio than that of broad leaf tree. In addition, broadleaved trees may allocate more biomass to their roots, especially the fine roots at the shallow soil horizons, which can fix a greater amount of carbon and transfer more root detritus to the top soil (Yang et al., 2004a, 2004b).

\section{Acknowledgments}

This work was supported by the Knowledge Innovation Program of the Chinese Academy of Sciences (No. KZCX2-YW-405) and the Innovation Group Project of National Natural Science Foundation of China (No. 40621061).

\section{References}

Bouwman A F, 1990. Exchange of greenhouse gases between terrestrial systems and the atmosphere. In: Soils and the Greenhouse Effect (Bouwman A F, ed.). Chichester: Wiley. 
Cannell M G R, 1982. World Forest Biomass and Primary Production Data. London: Academic Press.

Chen C Y, Liao L P, Wang S L, 2000. Ecology of Chinese Fir Plantation Forest. Beijing: Science Press. 1-39, 84-96.

Chen C Y, Wang S L, 2004. Ecology of Mixed Plantation Forest. Beijing: Science Press. 3.

Chen C Y, Zhang J W, Zhou C L, Zheng H Y, 1990. Researches on improving the quality of forest land and the productivity of artificial Cunninghamia lanceolata stands. Journal of Applied Ecology, 1(2): 97-106.

Dewar R C, Cannell M G R, 1992. Carbon sequestration in the trees, products and soils of forest plantations: an analysis using UK examples. Tree Physiology, 11: 49-71.

Dong M, 1997. Survey, Observation and Analysis of Terrestrial Biocommunities. Beijing: Standards Press of China.

Feng Z W, Chen C Y, Zhang J W, 1988. A coniferous broad-leaved mixed forest with higher productivity and ecological harmony in subtropics - study on mixed forest of Cunninghamia lanceolata and Michelia macchurei. Acta Phytoecologica et Geobotanica Sinica, 12(3): 165-180.

Grigal D F, Ohmann L F, 1992. Carbon storage in upland forests of the Lake States. Soil Science Society of America Journal, 56: 935-943.

Harmon M E, Ferrell W K, Franklin J F, 1990. Effects on carbon storage of conversion of old-growth forests to young forests. Science, 247: 699-702.

Lao J C, 1988. Handbook for Soil and Agro-chemical Analysis. Beijing: Chinese Agriculutural Press.

Liu G S, 1996. Soil Physical and Chemical Analysis and Description of Soil Profiles. Beijing: Standards Press of China.

Mo J M, Sandra B, Peng S L, Kong G H, Zhang D Q, Zhang Y $\mathrm{C}, 2002$. Role of understory plants on nutrient cycling of a restoring degraded pine forests in a MAB reserve of subtropical China. Acta Ecologica Sinica, 22(9): 14071413.

Schroeder P, 1992. Carbon storage potential of short rotation tropical tree plantations. Forest Ecology and Management, 50: 31-41.

Wang Q K, Wang S L, Huang Y, 2008. Comparisons of litterfall, litter decomposition and nutrient return in a monoculture Cunninghamia lanceolata and a mixed stand in southern China. Forest Ecology and Management, 255: 1210-1218.

Wu Z L, 1984. Chinese-fir. Beijing: Forestry of China Publications.

Yang Y S, Chen G S, Guo J F, Lin P, 2004a. Decomposition dynamic of fine roots in a mixed forest of Cunninghamia lanceolata and Tsoongiodendron odorum in mid-subtropicals. Annals of Forest Science, 61: 65-72.

Yang Y S, Chen G S, Lin P, Xie J S, Guo J F, 2004b. Fine root distribution, seasonal pattern and production in four plantations compared with a natural forest in subtropical China. Annals of Forest Science, 61: 617-627.

Yang Y S, Guo J F, Chen G S, Lin R Y, Cai L P, Lin P, 2004c. Litterfall, nutrient return, and leaf-litter decomposition in four plantations compared with a natural forest in subtropical China. Annals of Forest Science, 61: 465-476.

Yang Y S, Guo J F, Chen G S, Xie J S, Zhen L, Zhao J, 2005. Carbon and nitrogen pools in Chinese fir and evergreen broadleaved forests and changes associated with felling and burning in mid-subropical China. Forest Ecology and Management, 216(1-3): 216-226.

Zhou Y R, Yu Z L, Zhao S D, 2000. Carbon storage and budget of major Chinese forest types. Acta Phytoecologica Sinica, 24(5): 518-522. 